\title{
An explorative study on the use of condom among direct commercial female sex workers in Sanur
}

\author{
LG Pradnyawati ${ }^{1 *}$ \\ ${ }^{1}$ Faculty of Medicine and Health Sciences, Universitas Warmadewa, Jl. Terompong No. 24 Denpasar - \\ Bali, 80235 \\ *pradnyawati86@gmail.com
}

\begin{abstract}
Previous studies on commercial female sex workers reported that the number of commercial female sex workers spreading throughout Denpasar city and its surroundings is 250 persons and $14 \%$ of them had been infected with HIV/ AIDS (Human Immunodeficiency Virus/ Acquired Immune Deficiency Syndrome). However, referring to the data in the City Health Service of Denpasar, the number of direct commercial female sex workers throughout Sanur area in 2017 is 450 persons. Theses number indicate that the risk of sexually transmitted infection among direct commercial female sex workers in the area is intensely high, with possibility that sex protection using condom is rather minimal. This study aims, to explore more about the condom use among the direct commercial female sex workers in Sanur. The study was performed based on qualitative research design. A purposive sampling technique was implemented by selecting 15 informants. These 15 informants consisted of: the direct commercial female sex workers, pimps, and customers, which were approached based on in-depth interviews. The results of data analysis showed that during sexual intercourses not all the direct commercial female sex workers applied the use of condoms. The leading reason was the male partners disliked the condoms in the sexual intercourse. However, it is also found that economic factor had given rise to avoiding the condom use. It should be noted well that using condoms during sexual intercourse decreases the growing number of the direct commercial female sex workers.

Keywords: Condom, Sexually Transmitted Infection, Commercial Female Sex Workers, Sanur
\end{abstract}

\section{Introduction}

STI (Sexually Transmitted Infections) is a group of diseases whose transmission occurs mainly through sexual intercourses. Based on WHO surveys, every year there are approximately 250 million new STI sufferers, which include Gonorrhea, Syphilis, Genital Herpes in the entire country throughout the world and such number seems to substantially grow overtime [1].

High-risk groups that are vulnerable to STIs are commercial female sex workers. This condition emerges as a risk of their profession [2]. Indonesia national researches have shown that, on average, commercial female sex workers serve 3 to 4 customers a day. In Indonesia, in Bali, Papua and East Java in particular, a female prostitute can serve 1 to 12 people in a day. Bali, which is one of the top destinations for travellers from all over the world, both for traveling, for business, for work and for study, is also a vulnerable area for the spread and transmission of STIs. 
Research conducted on commercial female sex workers in 2007 revealed that there were 250 female sex workers in Denpasar and its surrounding areas and approximately $14 \%$ among them contracted HIV / AIDS (Human Immune Deficiency Virus / Acquired Immune Deficiency Syndrome). Generally, the female sex workers who have HIV / AIDS are between 20-30 years old. Based on the data obtained from Denpasar City Health Office, in 2017 there were 900 direct commercial female sex workers throughtout Denpasar City and the South Denpasar Sub-district, Sanur area, is the area twith the highest rate of STI cases [3]. Furthemore, recent data shows that in 2017 there were 450 direct commercial female sex workers in the Sanur area. In the area there are many locations and spots for sexual transactions.In Sanur area, Danau Tempe is the hotspot locations for sexual workers

Based on brief description above, the transmission of STIs among female sex workers in Sanur is considered as high Therefore, by the present study an explorative study was conducted to explore the use of condoms for the the prevention of the STIs transmission in the direct female sex workers.

\section{Method}

This study conducted was designed using qualitative method with a phenomenological approach. The research participants were selected by applying purposive sampling technique. These participants were female sex workers, pimps, and their customers. These participants were selected based on several inclusive criteria namely: direct commercial female sex workers under productive age (18-45 years), are agree to be informants, are able to communicate well and are able to provide the required information.

The number of sample of the research participants were determined based the required information guided by the nature of qualitative research. Thus the number of participants included in the present study is 15 persons, which were respectively 5 person taken from the direct female sex workers, 5 persons taken from the pimps, and the other 5 persons were taken from the customers. To collect the required data, in-depth interviews were conducted to these selected informants. Interviews were ended right at peak of saturation in order to extract the original information related to sexual works and the STIs transmittal from the participants. These data were analyzed thematically with a qualitative-verification data analysis model, wherein, after the data was collected, each was classified to draw conclusions that refers to the theory and related literature sources, according to the theme discovered..

\section{Results And Discussion}

Most participants are familiar with the functions of condoms. It was admitted that the function of condoms was to prevent pregnancy, to avoid STI disease, and is a contraceptive device. The following are the excerpts from the statement of the participants.

The condoms are used to prevent pregnancy. They also can be used to prevent the sexually transmitted diseases. I have ever read the functions of using condoms on the internet. But, you know, condoms are made of rubber, so they will be sometimes leak. That's why it cannot be claimed capable of making safe.'

(NI, female direct CSW, 19 years old) 
'Yes, the condoms are to avoid pregnancy. What's others, Men? I think that's all. Perhaps they can be the family planning too. That's what I heard.'

(AM, pimp, 52 years old)

'Yes. Condoms can also be a prevention of sexually transmitted diseases, right? Like HIV. They are used to make safe though.'

( $K W$, customer, 43 years old)

Although the condom use has been encouraged, there are still many participants who claim not to use condoms during sexual intercourse with the customers. Most of them revealed some reasons that are, their partners did not like the use of condoms in sexual intercourse. In addition, some participants also stated that they had used contraceptives in the form of family planning, so they no longer needed condom use, other than because their male partners were not satisfied when using condoms. However, some participants also used condoms when dealing in sexual intercourse with customers. The following are the excerpts from the statement of the participants.

'I do not use condoms because I always use a-three months contraceptive injection. All the more, my customers do not like condoms.'

(NI, female direct CSW, 19 years)

'I have never used condoms (during sexual intercourse) with my partners'. The told me they hate condoms. The would not feel satisfied with condoms. To my need of money, I just follow them.'

(IJ, female direct CSW, 35 years old)

'Never. My partners admitted they hate condoms.' Whenever I offer to use condom, they often ask me to cut half of the fee. That will make me disadvantaged.'

( $P U$, female direct $C S W, 19$ years)

When participants do not use condoms when dealing with customers, it does not mean they really dislike condoms. In fact, the participants are afraid infected by STIs. However, they were afraid customers will be unsatisfied and finally they drop off. When that happens, their income is affected and their economic needs would be threatened difficult to fulfill. To avoid this, participants are compliant to not use the condoms during having sexual intercourse with their customers. The following are excerpts of statements from the participants.

'I am actually apprehensive. Even less there have been many kinds of sexually transmitted diseases today. But, what to do, I need the money. I have a lot of burdens at home.'

(IJ, female direct $C S W, 35$ years)

'I can't do any other things to fulfill my needs of food.' Hahah ... I hope I will not risk but if I get sick I will just see the doctor. It's actually because if urge my customer to use the condoms, they will pay me cheaper. Once my customer admitted that with condoms their penetration goes smoothly and makes little satisfaction but without condoms the penetration goes densely and the satisfaction is felt fully.'

( $P U$, female direct $C S W, 18$ years) 
'Whenever I am going to do the sexual intercourse, I actually have provided many condoms. I keep them under my pillows. I often try to persuade him to use the condoms but he never heed for he will lack of satisfaction. Even once in the darkness, I did an oral sex and secretly put on the condom on him. He was immediately aware of it and put it off back. So we did the intercourse without condoms.'

'I am indeed apprehensive of being infected by diseases. I will never know with whom they have done sexual intercourse. Still, to avoid discommodity, it would be better to take it. You know, it's too difficult to get food today.'

(RA, female direct CSW, 22 years)

The pimps at the location admit to have always advised both the female sex workers and their service users to always use condoms when dealing in the intercourse. However, in practice there are still many of them who do not use the condoms during sexual intercourse. Most pimps claimed to have attended an extension program on the benefits of condom use organized by a community health center or foundation. The following are quotes from participants' statements.

'Indeed I have always encouraged them (the female sex workers) whenever I hold gatherings with them. However they still ignore it as their customers think the condoms do not make them satisfied. The children (the female sex workers) want their customers not to drop off.'

(AM, pimp, 52 years old)

I I always ask them to use condoms. Sometimes, before they got in the room, I encourage the customers to use it. They agreed on words but they did not do it as had been in the room. The customers are naughty. As they were finished, my workers told me they had not used it.'

(NA, pimp, 43 years old)

'I have never forgot to remind them to use condoms. But, I couldn't make sure whether they obey it during being in the room or not. Anyway, I often tell my workers to see the doctor if they find any pus comes out of their genitals.'

'I was told of it by the officers from the hospital'. Even, there used to be extension programs. The Chair of the Community Health Center foundation of Sesetan often come here to do checks on my workers.'

(VA, pimp, 48 years old)

Most of the customers claim that they dislike using condoms during sexual intercourse with the direct commercial female sex workers. They confessed that they came to the location to pay for women and then to get satisfaction. In case they use a condom during having sexual intercourse, they feel unsatisfactory and uncomfortable. Hence, if they are required to use the condoms, they will deduct the payments from the amount they should pay off. Even for their satisfaction, complaints on their genitals will never be a burden since they think to overcome such diseases, they simply come to the doctor and they will get cured. The following are quotes from participants' statements. 
'I hate condoms. It never makes me comfortable and satisfied. If one day I get infected with any diseases, I simply come to the doctor. Fortunately I am OK. I have always been here since last a year. The workers are attractive. Hahaha...'

'There are a lot condoms in the room. The pimp may have prepared it on purpose. But, I really don't like tem.'

(PA, customer, 21 years old)

'What needs for condoms?. I come to pay for women, so I'm paying for my satisfaction. I'll just get disavantaged if I use condoms. Condoms makes me lack of comfortability and satisfaction.'

'They used to offer condoms for me, but I rejected them. I always ask to cut half of the fee if they force me to use the condoms, then they just took it. The their boss even often reminds me to use the them, but during being in the room I igore it. Hehehe...'

(AH, customer, 27 years old)

A study on relationship between individual perceptions of the risk of HIV infection was conducted by Prata and Mozambik (2015). results of their study revealed that $27 \%$ of women and $80 \%$ of men believe that they did not experience the risk of sexual intercourse, or in other words the possibility of being infected with HIV is very small even though they were actually classified as moderate or high-risk groups. Therefore the knowledge factor is very influential in changing HIV prevention behavior in Mozambique [4].

A study conducted by Lokollo on Indirect Female Sexual Workers (FSW) in Semarang City showed that most of the indirect FSWs did not directly admit that they belonged to a high-risk group but their knowledge and practice of STI prevention efforts was totally lacking. Despite of their approbation of that using the condoms is a good strategy and effort to prevent the STI transmittal, in practice, during every sexual intercourse, condoms are not always applied. Their bargaining position is still low in negotiating the condom use with their clients. In addition, supports from their families and peers in preventing the STIs is still very poor [5].

The increased cases of STI incidents from time to time will cause very serious health problems for the community and have a major impact in the future if they do not get intensive attention and treatment. STIs in many countries are considered a serious global threat, with the impact suffered by individuals, families and communities. In some countries, STIs and their complications are ranked fifth of the main reasons for adult patient treatment. The impact of STIs on women is usually complicated and difficult to diagnose, because generally they are asymptomatic, the sufferers' guilt or reluctance arises to seek treatment, so that they becomes an undisclosed burden for them [6].

An analytical survey with quantitative and qualitative methods conducted by Khosidah and Purwanti in 2014 regarding the perception of housewives about VCT (Voluntary Counseling and Testing) tests on HIV / AIDS prevention behaviors in Banyumas Regency revealed that most housewives do consider the HIV / AIDS is a serious disease. A person's actions to seek treatment and prevent the disease are driven by the serious threat of it [7].

Another research conducted by Lestari in 2013 regarding the problem of seeking STI care for female sex workers (FSW) in the village of Empakuq Melak Subdistrict, West Kutai District with qualitative research design and case study approach found that all FSW considered STIs to be a serious disease. They claimed that they belong to a high-risk group of 
the disease but their practice of prevention is still insufficient. All of the FSW claimed to go to the doctor and some claimed to use traditional herbs to treat themselves [8].

Knowledge is an important domain that triggers the formation of a perception and action on a person. The research conducted by Matahari in 2012 on the perceptions and sexual behaviour of female commercial sex workers (CSWs) in the efforts to prevent STIs in Semarang City revealed that most sex workers believe that STIs are not a serious disease because they can still be cured using doctor medicine. In their understanding, STIs are said to be serious if they have entered the AIDS phase. Unlike low-educated groups, highly-educated CSWs recognize that STIs are a serious disease because they can transmit to others. Meanwhile, the perception of CSWs with a low education on STI cases is that the serious type of STIs are AIDS, while other types of STIs are excluded from the alignment of the severe disease because they can still be treated [9].

The perceptions of female sex workers in the form of their knowledge of the causes, modes of transmission, consequences and methods of prevention of STIs are directed according to their ability to think about what they see and experience themselves. Again, knowledge is an important domain for the formation of one's actions. Research on 239 respondents in Turkey outlined a low education and a higher age group did not become a significant predictor of low knowledge scores. Low education is not an independent risk factor for awareness, but higher age group participants have a significantly lower level of awareness of the risks associated with sexually transmitted infections [10].

An observational study, conducted by Budiman and Istiarti in 2008 about factors related to the practice of female sex workers (WPS) in the efforts to prevent STIs and HIV / AIDS around the square and Candi Prambanan in Klaten Regency, trotted out that $75 \%$ of FSW confessed that STIs and HIV / AIDS are very serious diseases but 13.6\% stated that they are not serious diseases. Most of the respondents are not familiar with the causes of the STIs and HIV \& AIDS and are not able to distinguish between the causes and modes of transmission of the STIs and HIV \& AIDS. Some respondents suppose the causes of STIs and HIV \& AIDS are the same as the way they are transmitted, that is due to sexual intercourse with partners who had contracted the disease [11].

\section{Conclusions}

Although condom use has been encouraged, most direct commercial female sex workers do not use condoms during sexual intercourse with their partners. The main factor for the low use of condoms is the dislike of male partners or customers for the condoms in order to maintain maximum satisfaction. Economic factors have become the main reason for the direct female sex workers to succumb to their efforts to offer condoms to their male partners. Forcing their male partners to use the condoms means forcing the cost to be reduced and eventually their income decreases

\section{References}

[1] WHO. (2013). Report on Global Sexually Transmitted Infection Surveillance 2013. 
[2] Hargono, A. (2012). Kajian Penggunaan Data Papsmear Ibu Rumah Tangga dalam Surveilans Infeksi Menular Seksual pada Kelompok Risiko Rendah ( Policy Study Use of Housewive Pap-Smear Data on the Sexually Transmitted Disease Surveillance at Low Risk Groups ). Buletin Penelitian Sistem Kesehatan, 15(4), 381-389.

[3] Dinas Keshatan Kota Denpasar. (2017). Laporan Tahunan Dinas Kesehatan Kota Denpasar. Denpasar.

[4] Prata BN, Morris L. Relationship Between HIV Risk Perception And Condom Use : Evidence from a Population-Based Survey in Mozambique. Guttmacher Inst 2015; 32: 192-200.

[5] Lokollo, F. Y. (2009). Studi Kasus Perilaku Wanita Pekerja Seksual Tidak Langsung dalam Pencegahan IMS, HIV dan AIDS di Pub \& Karaoke, Café, dan Diskotek di Kota Semarang. Program Studi Magister Promosi Kesehatan Program Pascasarjana Universitas Diponegoro. Tesis Program Studi Magister Promosi Kesehatan Universitas Diponegoro.

[6] Widyastuti, W. (2007). Perilaku Menggunakan Kondom pada Wanita Penjaja Seks Jalanan di Jakarta Timur Tahun 2006. Jurnal Kesehatan Masyarakat Nasional, Volume 1, 161-167.

[7] Khosidah, A., \& Purwanti, S. (2014). Persepsi Ibu Rumah Tangga tentang Voluntary Counselling and Testing (VCT) terhadap Perilaku Pencegahan HIV/AIDS. Jurnal Ilmiah Kebidanan. 5(2), 67-78.

[8] Lestari, L. (2013). Pola Pencarian Perawatan Infeksi Menular Seksual pada Perempuan Pekerja Seks di Desa Empakuq Kecamatan Melak Kabupaten Kutai Barat.

[9] Matahari, R. (2012). Studi Kualitatif Mengenai Persepsi dan Perilaku Seksual Wanita Pekerja Seks Komersial (PSK) dalam Upaya Pencegahan IMS di Kota Semarang Tahun 2012. Jurnal Kesehatan Reproduksi, Volume 3.

[10]Ersan, G. (2012). Knowledge and Awareness of Female Sex Workers Towards Human Papillomavirus Infection in Turkey, 20(3), 219-222.

[11] Budiman, N. A., \& Istiarti, T. (2008). Faktor-Faktor Yang Berhubungan Dengan Praktik Wanita Pekerja Seks ( WPS ) Jalanan Dalam Upaya Pencegahan IMS Dan HIV / AIDS Di Sekitar Alun-Alun Dan Candi Prambanan Kabupaten Klaten. Jurnal Promosi Kesehatan Indonesia, Volume 3. 